\title{
Bevacizumab in HER2neu Negative Locally Recurrent and Metastatic Breast Cancer: The BHerN Review
}

\author{
Mary Ondinee U. Manalo, Mark Anthony E. Agana and Corazon A Ngelangel
}

Section of Medical Oncology, Department of Medicine, College of Medicine and Philippine General Hospital, University of the Philippines Manila

\begin{abstract}
Introduction. A promising strategy for HER2-negative metastatic breast cancer ( $\mathrm{mBC}$ ) is to target the vascular endothelial growth factor receptor using bevacizumab. Several randomized controlled trials (RCTs) have consistently demonstrated improvement in progression-free survival (PFS).

Methods. This meta-analysis was undertaken to determine the added benefit of bevacizumab (BV) to chemotherapy in HER2-negative locally recurrent and mBC. RCTs that compared the efficacy and safety of BV+chemotherapy to placebo+chemotherapy in the first- or second-line setting were selected. The primary outcome was PFS. The secondary outcome measures were overall survival (OS) and objective response rate (ORR). Analysis of safety was done by pooling grades 3-5 toxicities. Four RCTs were included in the meta-analysis: E2100, AVADO, RIBBON-1, and RIBBON-2.

Results. The use of BV+chemotherapy showed statistically significant improvement in PFS (HR 0.73 [0.65, 0.82] 95\% Cl, $\mathrm{p}<0.0001)$; subgroup analysis of triple-negative breast cancer (TNBC) also showed statistically significant increase in PFS (HR $0.56[0.47,0.67] 95 \% \mathrm{Cl}, \mathrm{p}<0.00001)$. The ORR was statistically significant with a risk ratio of 1.36 in favour of $B V(p<0.00001)$. OS did not reach statistical significance (HR $0.85[0.56,1.27] 95 \% \mathrm{Cl}$, $\mathrm{p}=0.42$ ). Grades 3-5 toxicities were consistently higher in the BV arm with a risk ratio of $1.90(\mathrm{p}<0.00001)$.
\end{abstract}

\footnotetext{
Presented and won First Place at the Philippine Society of Oncology Annual Research Forum and 29th Annual Convention of the Philippine Society of Oncology, Inc., September 2013, Manila Diamond Hotel; presented and won Second Place, Dr. Reuben C. Guerrero Annual Cancer Research Forum Contest, Philippine Society of Medical Oncology 26th Annual Convention, October 2012, EDSA Shangri-La, Manila; presented and a finalist, UP-PGH Department of Medicine Annual Research Forum, September 2012, Guazon Hall, Philippine General Hospital.

Corresponding author: Corazon A. Ngelangel, MD, MS, PhD

Section of Medical Oncology

Department of Medicine

Philippine General Hospital

University of the Philippines Manila

Taft Avenue, Ermita, Manila 1000 Philippines

Tele/Fax: +632 5263775

Email: corazon.ngelangel@gmail.com
}

Conclusion. BV prolongs PFS and increases ORR in patients with HER2-negative locally-recurrent and $\mathrm{mBC}$. OS was comparable in both arms. Toxicities significantly increased with the addition of BV to chemotherapy, but fatal reactions were rare in all four trials. The addition of BV to conventional first- or second-line chemotherapy is justified in $\mathrm{TN} \mathrm{mBC}$ since there is still no standard treatment for this.

Key Words: bevacizumab, HER2 negative, triple negative metastatic breast cancer

\section{Introduction}

Breast cancer is the most common malignancy in women worldwide. In the Philippines, more than 18,000 were diagnosed in the Manila and Rizal area in $2010 .{ }^{1}$ In the Cancer Institute of the Philippine General Hospital, the Breast Care Clinic and the Medical Oncology Clinic see about 60 breast cancer patients per day.

Breast cancer represents a heterogeneous malignancy that is diversified by its immune-histochemical features, behavior, outcome and response to treatment. ${ }^{2}$ De Vita describes that breast cancer has several molecular subtypes, namely; luminal A and B, HER2 over-expressing and basallike breast. ${ }^{3}$

The human epidermal growth factor receptor 2 (HER2)/neu is a growth factor receptor gene that is amplified in approximately $20-25 \%$ of breast cancers with its corresponding encoded protein also being detected at abnormally high levels in these malignant cells. Its main function is to mediate growth, differentiation, and survival of cells. Amplification of HER2, is known to be associated with reduced disease-free and OS compared with patients with HER2-negative disease. ${ }^{4,5}$ With the introduction of trastuzumab, a monoclonal antibody directed against the HER2 receptor, both PFS and OS have improved essentially, thus changing the natural history of HER2-positive mBC. ${ }^{6}$ Presently, ER/PgR-negative HER2-negative status is associated with a poorer prognosis because of lack of standard therapy. ${ }^{5}$ And this is even more important because $80 \%$ of breast cancers are HER2-negative.

Angiogenesis is a complex process whereby a vasculature develops that involves a balance between many stimulating and inhibitory factors. The key regulator of angiogenesis is the vascular endothelial growth factor (VEGF) and its receptor system. ${ }^{7}$ VEGF is essential during 
early stages of tumorogenesis and plays a key role in tumor metastasis. The transition of the tumor from avascular to vascular phase, termed angiogenic phase, is said to be the hallmark of the malignant process. ${ }^{8}$ Studies on early breast cancer have showed high expression of VEGF. Its expression is responsible throughout the growth and development of the tumor, and has been associated with shorter relapse-free survival and over-all survival times in patients either with positive or negative lymph nodes. Therefore, inhibition of VEGF causes regression of the tumor vasculature, prevents neovascularization and promotes normalization of the remaining blood vessels. ${ }^{9,10}$

One promising strategy is to target the VEGF, either by ligand sequestration or inhibiting downstream receptor. The European Medicines Agency (EMA) approved bevacizumab, a humanized monoclonal antibody directed against VEGF by ligand sequestration as a first line treatment for advanced breast cancer. It binds and neutralizes all biologically active isoforms of VEGF. It has been approved for lung cancer, renal cell cancer, colorectal cancer, glioblastoma multiforme, and for ovarian cancer.

$\mathrm{BV}+$ chemotherapy, particularly with taxane were shown to improve the efficacy of treatment of $\mathrm{mBC}$ in phase I and II trials. These studies have shown improvement of ORR and median time to progression (TTP). ${ }^{11}$ There was shown a $36 \%$ lower risk of PFS with addition of BV to chemotherapy in patients with $\mathrm{mBC}$. $^{12,13}$

At present, there is no standard treatment for ER/PgRnegative HER2-negative breast cancer in the locallyrecurrent and the metastatic. ${ }^{8}$ New treatments that could delay disease progression without systemic toxicity would represent a significant advancement. Also, there are conflicting data on the real benefit of BV in $\mathrm{mBC}$. It is in this light that this meta-analysis was done.

This study evaluates the efficacy of BV+chemotherapy versus chemotherapy alone in the treatment of locallyrecurrent or metastatic HER2-negative breast cancer by measuring the PFS.

\section{Methods}

\section{Search Strategy}

The meta-analysis was performed according to a predefined protocol. To be eligible, the studies had to be Phase III clinical trials that dealt with HER2-negative metastatic or locally recurrent breast cancer. The studies should involve BV in addition to any chemotherapy versus a placebo plus chemotherapy (up to June 2012). Studies were identified by an electronic search engine using online PubMed. The search terms used were "bevacizumab", "antiVEGF", "breast cancer", "locally recurrent breast cancer", "metastatic breast cancer" and "HER2-negative breast cancer". Another electronic search using the same key words at ClinicalTrials.gov was performed. The initial selection of articles relied on careful reading of their abstracts. Abstracts were reviewed from the American Society of Clinical Oncology proceedings as well. References from relevant literature were screened, including all of the identified studies. Trial authors were contacted to obtain the full text of some articles. Duplication of data was avoided by examining for each publication the names of all authors and the different medical centers involved. The search was limited to randomized controlled trials. No language restriction was imposed.

\section{Study Selection Criteria}

The reviewers browsed through the titles and abstracts of studies identified in the electronic and hand search for possible inclusion. Full texts of studies judged to be relevant were retrieved and independently assessed for inclusion by the reviewers. A study was considered relevant if it met the following inclusion criteria: it is a Phase III clinical trial; it involved adult subjects with at least a subgroup consisting of HER2-negative breast cancer; BV was used in combination with chemotherapy and was compared to placebo plus chemotherapy; PFS, OS, ORR, and adverse events were reported.

Studies that met the inclusion criteria were then evaluated for methodological quality using the Jadad scale. This was done independently by the reviewers. Conflicts were resolved by consensus.

\section{Data Collection and Statistical Analysis}

Data were extracted independently by the reviewers. The following data were obtained from each study: title, author and year of publication, total population of the study and the population for each treatment arm, PFS, OS, ORR, and incidence of grades 3-5 adverse events.

PFS, defined as the time from randomization to disease progression, and OS, defined as the time from randomization to death from any cause, was measured in months. ORR was assessed according to Response Evaluation Criteria in Solid Tumors (RECIST) version 1.1 (http://www.recist.com/). Analysis of safety was also done by pooling grades 3-5 toxicities as graded by the National Cancer Institute Common Toxicity Criteria for Adverse Events (NCI-CTCAE) version 4.0 (USA NIH-NCI, 2009). Subgroup analysis for survival data for TNBC was done. Any discrepancy between the reviewers was resolved by discussion and consensus.

The analytic approach and software provided by the Cochrane Collaboration was used for all analyses (Review Manager (RevMan) [Computer program]. Version 5.0 Copenhagen: The Nordic Cochrane Centre, The Cochrane Collaboration, 2008. Cochrane Centre, Copenhagen, Denmark). For the quantitative measure of survival, hazard ratio and their 95\% confidence interval were taken based on the data that was provided by the publication. Findings 
were considered to be statistically significant if the test for overall effect has a p-value $<0.05$. The risk estimates and confidence intervals were illustrated using forest plots. Heterogeneity was assessed through the $x^{2}$ test and quantified using the $I^{2}$ test.

The final report was written in accordance with the Preferred Reporting Items for Systematic Reviews and MetaAnalyses (PRISMA).

\section{Results}

\section{Study Selection}

A total of 174 trials were considered for inclusion. 157 studies were excluded after the initial screening. 14 studies were excluded after review of the full texts. The final metaanalysis included a total of 4 trials in the final review with a total of 1,667 subjects who were included in the final analysis. Summarized in Figure 1 is the search and study selection process.

\section{Study Characteristics}

The main features of the eligible studies are summarized in Table 1. All four studies compared BV+ chemotherapy to placebo+chemotherapy. In E2100, AVADO, and RIBBON-1, BV was given as first line for mBC. RIBBON2 tested BV as a second-line treatment. These studies did not include purely HER2-negative individuals. Some were HER2-positive and were enrolled only if they were on or have failed trastuzumab. Since the purpose of this metaanalysis was to determine the added benefit of $\mathrm{BV}$ to standard chemotherapy in HER2-negative mBC patients, we extracted the purely HER2-negative subsets and used these in our analysis. The main features of the excluded studies are summarized in Appendix 1. Ongoing studies are shown in Appendix 2.

\section{Assessment of Bias}

The four studies included in the meta-analysis were assessed for quality of methodological reporting. Studies were rated independently by the reviewers with one of the reviewers blind to the study title, name and publication details. The detailed methodological quality of the individual studies is shown in Table 2. All of the studies were judged to be of high methodological reporting quality via the Jadad scale.

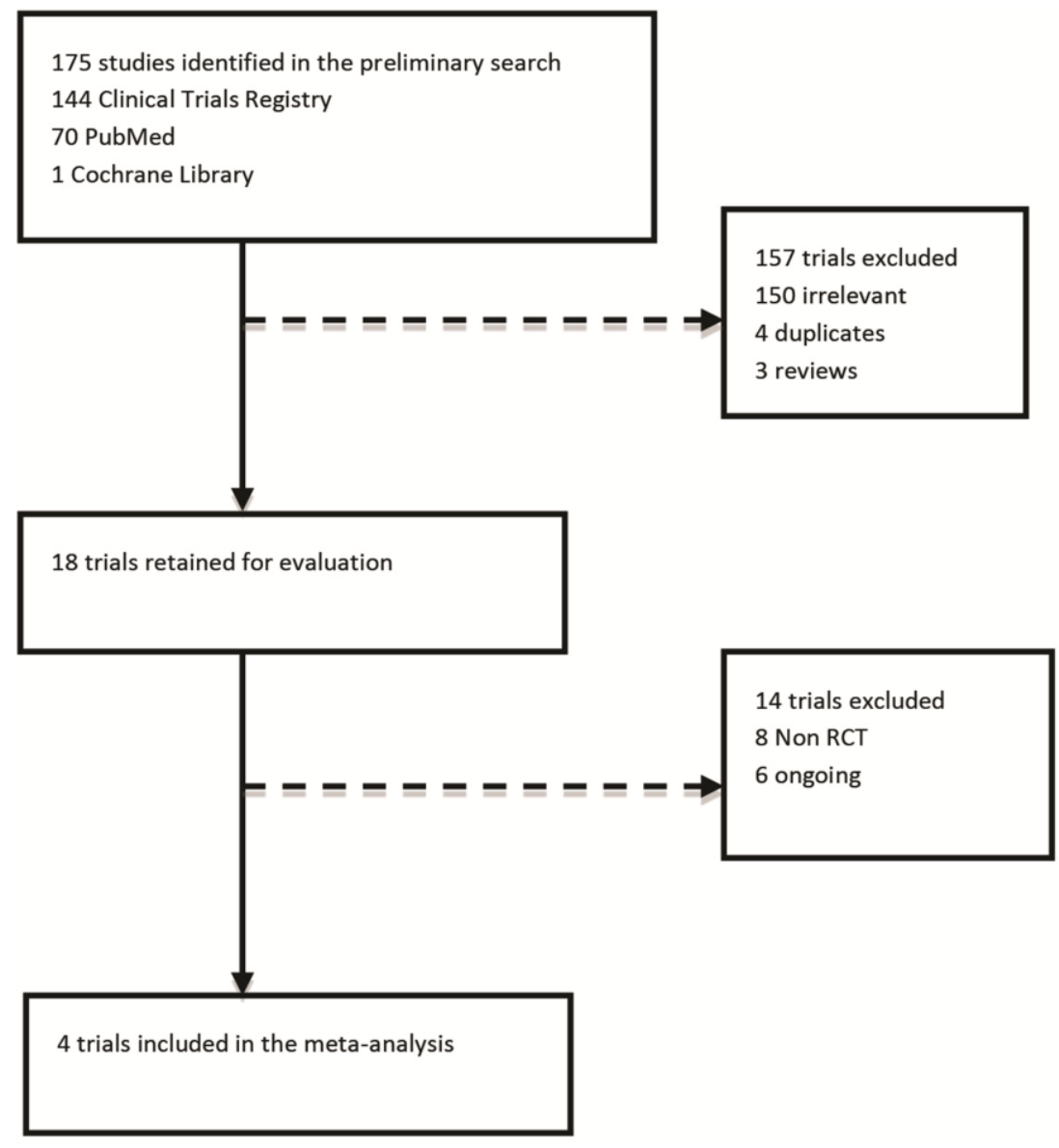

Figure 1. Literature Search and Study Selection 
Table 1. Study RCTs

\begin{tabular}{|c|c|c|c|c|}
\hline & E2100 2007 & AVADO 2010 & RIBBON-1 2011 & RIBBON-2 2011 \\
\hline Citation & $\begin{array}{l}\text { Miller K, Wang M, Gralow J, } \\
\text { Dickler M, Cobleigh M, Perez } \\
\text { EA, Shenkler T, Celia D, and } \\
\text { Davidson NE. Paclitaxel plus } \\
\text { bevacizumab versus Paclitaxel } \\
\text { Alone for Metastatic Breast } \\
\text { Cancer. N Engl J Med } \\
\text { 2007;357:2666-67. }\end{array}$ & $\begin{array}{l}\text { Miles DW, Chan A, Dirix LY, } \\
\text { Cortes J, Pivot X, Tomczak P, } \\
\text { Delozier T, Sohn JH, } \\
\text { Provencher L, Puglisi F, } \\
\text { Harbeck N, Steger GG, et al. } \\
\text { Phase III Study of } \\
\text { Bevacizumab plus Docetaxel } \\
\text { Compared with Placebo Plus } \\
\text { Docetaxel for the First-Line } \\
\text { Treatment of Human } \\
\text { Epidermal Growth Factor } \\
\text { Receptor2-Negative Metastatic } \\
\text { Breast Cancer. J ClinOncol } \\
\text { 2010; 28:3239-3247. }\end{array}$ & $\begin{array}{l}\text { Robert NJ, Dieras V, Glaspy J, } \\
\text { Brufsky AM, Bondarenko I, } \\
\text { Lipatov ON, Perez EA, Yardley } \\
\text { DA, Chan SYT, et al. RIBBON-1: } \\
\text { Randomized, Double-Blind, } \\
\text { Placebo-Controlled, Phase III Trial } \\
\text { of Chemotherapy With or } \\
\text { Without Bevacizumab for First- } \\
\text { Line Treatment of Human } \\
\text { Epidermal Growth Factor } \\
\text { Receptor 2-Negative, Locally } \\
\text { Recurrent or Metastatic Breast } \\
\text { Cancer. J ClinOncol 2011; 29:1252- } \\
\text { 1260. }\end{array}$ & $\begin{array}{l}\text { Brufsky AM, Hurvitz S, Perez, } \\
\text { Swamy R, Valero, O'Neill V, and } \\
\text { Rugo HS. RIBBON-2: A } \\
\text { Randomized, Double-Blind, } \\
\text { Placebo-Controlled, Phase III } \\
\text { Trial Evaluating the Efficacy and } \\
\text { Safety of Bevacizumab in } \\
\text { Combination With } \\
\text { Chemotherapy for Second-Line } \\
\text { Treatment of Human Epidermal } \\
\text { Growth Factor Receptor 2- } \\
\text { Negative Metastatic Breast } \\
\text { Cancer. J ClinOncol 2011; 29:4286- } \\
\text { 4293. }\end{array}$ \\
\hline $\begin{array}{l}\text { Type of } \\
\text { Study }\end{array}$ & $\mathrm{RCT}$ at $1: 1$ & $\mathrm{RCT}$ at $1: 1$ & $\mathrm{RCT}$ at $2: 1$ & RCT at $2: 1$ \\
\hline $\begin{array}{l}\text { Number of } \\
\text { Participants }\end{array}$ & $133: 118$ & $247: 219$ & $177: 67$ & $459: 225$ \\
\hline \multirow[t]{2}{*}{ Inclusion } & $\begin{array}{l}\text { All kinds, majority are HER2- } \\
\text { negative } \\
\text { mBC }\end{array}$ & $\begin{array}{l}\text { HER2-negative, LR or mBC } \\
\text { No prior chemotherapy for } \\
\text { advanced disease }\end{array}$ & $\begin{array}{l}\text { LR or mBC untreated with } \\
\text { chemotherapy } \\
\text { ECOG } 0-1\end{array}$ & $\begin{array}{l}\text { LR or } \mathrm{mBC} \text { who had received one } \\
\text { prior cytotoxic treatment for } \mathrm{MBC} \\
\text { ECOG } 0-1\end{array}$ \\
\hline & $\begin{array}{l}\text { No prior chemotherapy for } \\
\text { advanced disease } \\
\text { If with previous taxane-based } \\
\text { chemotherapy, must have a } \\
\text { disease-free interval of at least } \\
12 \text { months } \\
\text { If HER2+, eligible only if given } \\
\text { trastuzumab } \\
\text { ECOG 0-1 } \\
\text { Measurable disease was not a } \\
\text { requirement }\end{array}$ & $\begin{array}{l}\text { If with previous taxane-based } \\
\text { chemotherapy, } 12 \text { months } \\
\text { must have elapsed before } \\
\text { randomization } \\
\text { If not taxane-based } \\
\text { chemotherapy, may be at least } \\
12 \text { months } \\
\text { Measurable disease was not a } \\
\text { requirement } \\
\text { ECOG 0-1 }\end{array}$ & $\begin{array}{l}\text { Measurable disease was not a } \\
\text { requirement }\end{array}$ & \\
\hline \multirow[t]{3}{*}{ Exclusion } & CNS metastasis & SCC & HER2-positive & HER2-positive \\
\hline & $\begin{array}{l}\text { Any antitumor activity in the } \\
\text { past } 21 \text { days }\end{array}$ & CNS metastasis & $\begin{array}{l}\text { Prior chemotherapy in the past } 12 \\
\text { months }\end{array}$ & $\begin{array}{l}\text { Prior BV or other VEGF-targeted } \\
\text { pathway therapy }\end{array}$ \\
\hline & & & CNS metastasis & CNS metastasis \\
\hline \multirow[t]{2}{*}{ Study Design } & $\begin{array}{l}\text { I: Paclitaxel } 90 \mathrm{mg} / \mathrm{m} 2 \text { on days } \\
1,8 \text {, and } 15 \text { of a } 28 \text {-day cycle }+ \\
\text { placebo }\end{array}$ & $\begin{array}{l}\text { I: Docetaxel } 100 \mathrm{mg} / \mathrm{m} 2 \text { on day } \\
1 \text { every } 3 \text { weeks for a max of } 9 \\
\text { cycles + placebo }\end{array}$ & I: Tax/anthracycline + Placebo & I: Chemotherapy + Placebo \\
\hline & $\begin{array}{l}\text { II: Paclitaxel } 90 \mathrm{mg} / \mathrm{m} 2 \text { on } \\
\text { days } 1,8 \text {, and } 15 \text { of a } 28 \text {-day } \\
\text { cycle + bevacizumab } 10 \mathrm{mg} / \mathrm{kg} \\
\text { on days } 1 \text { and } 15 \text { continued } \\
\text { until disease progression or } \\
\text { with unacceptable toxicity }\end{array}$ & $\begin{array}{l}\text { II: Docetaxel } 100 \mathrm{mg} / \mathrm{m} 2+ \\
\text { bevacizumab } 15 \mathrm{mg} / \mathrm{kg} \text { on day } \\
1 \text { every } 3 \text { weeks continued } \\
\text { until disease progression or } \\
\text { with unacceptable toxicity }\end{array}$ & $\begin{array}{l}\text { II: Tax/anthracycline + } \\
\text { bevacizumab } 15 \mathrm{mg} / \mathrm{kg} \text { every } 3 \\
\text { weeks }\end{array}$ & $\begin{array}{l}\text { II: Chemotherapy + bevacizumab } \\
\text { at } 10 \mathrm{mg} / \mathrm{kg} \text { every } 2 \text { weeks or } \\
\text { bevacizumab at } 15 \mathrm{mg} / \mathrm{kg} \text { at } 3 \\
\text { weeks until disease progression } \\
\text { or with unacceptable toxicity }\end{array}$ \\
\hline $\begin{array}{l}\text { Primary } \\
\text { Endpoint }\end{array}$ & PFS & PFS & PFS & PFS \\
\hline $\begin{array}{l}\text { Secondary } \\
\text { Endpoint }\end{array}$ & OS, Safety & ORR, DOR, TTP, OS, Safety & ORR, OS, DOR, Safety & ORR, OS, DOR, Safety \\
\hline
\end{tabular}


Table 2. Risk of Bias in Studies

\begin{tabular}{lllll}
\hline & E2100 2007 & AVADO 2010 & RIBBON-1 2011 & RIBBON-2 2011 \\
\hline Sequence Generation & $\begin{array}{l}\text { Use of permuted blocks } \\
\text { within strata }\end{array}$ & $\begin{array}{l}\text { Use of interactive voice } \\
\text { response system }\end{array}$ & $\begin{array}{l}\text { Use of interactive voice } \\
\text { response system }\end{array}$ & $\begin{array}{l}\text { Hierarchical dynamic } \\
\text { randomization algorithm using an } \\
\text { interactive voice response system }\end{array}$ \\
$\begin{array}{l}\text { Allocation } \\
\text { Concealment }\end{array}$ & Did not say & Did not say & Did not say & Did not say \\
Blinding & Yes & Yes & Yes & Yes \\
$\begin{array}{l}\text { Incomplete Outcome } \\
\text { Data Addressed }\end{array}$ & $\begin{array}{l}\text { Intention to treat analysis } \\
\text { was done }\end{array}$ & $\begin{array}{l}\text { Intention to treat analysis } \\
\text { was done }\end{array}$ & $\begin{array}{l}\text { Intention to treat analysis } \\
\text { was done }\end{array}$ & $\begin{array}{l}\text { Intention to treat analysis was } \\
\text { done }\end{array}$ \\
Jadad & 5 & 5 & 5 & 5 \\
\hline
\end{tabular}

\section{Summary of Results}

Since we did not have the raw data of the studies evaluated, standard errors were derived for each of the studies. In our analysis, the use of BV+chemotherapy showed statistically significant improvement in PFS (HR 0.73 [0.65, 0.82] 95\% CI, $\mathrm{p}<0.0001$ ) (Figure 2). In E2100, RIBBON-1, and RIBBON-2, a substantial number of persons had TNBC. Subgroup analysis of this group also showed statistically significant increase in PFS (HR $0.56[0.47,0.67] 95 \%$ CI p<0.00001) (Figure 3). In those with measurable disease, the ORR was statistically significant with a risk ratio of 1.36 in favour of BV (p<0.00001) (Figure 4). OS was not statistically significant (HR 0.85 [0.56, 1.27] 95\% CI, p=0.42) (Figure 5). Grades 3-5 toxicities were consistently higher in the BV arm with a risk ratio of 1.90 ( $\mathrm{p}<0.00001$ ) (Figure 6).The plots for PFS and ORR were all homogenous. However, the plots for OS and occurrence of toxicities were heterogenous. We attribute this to the variability of the kinds and doses of chemotherapy used together with BV.

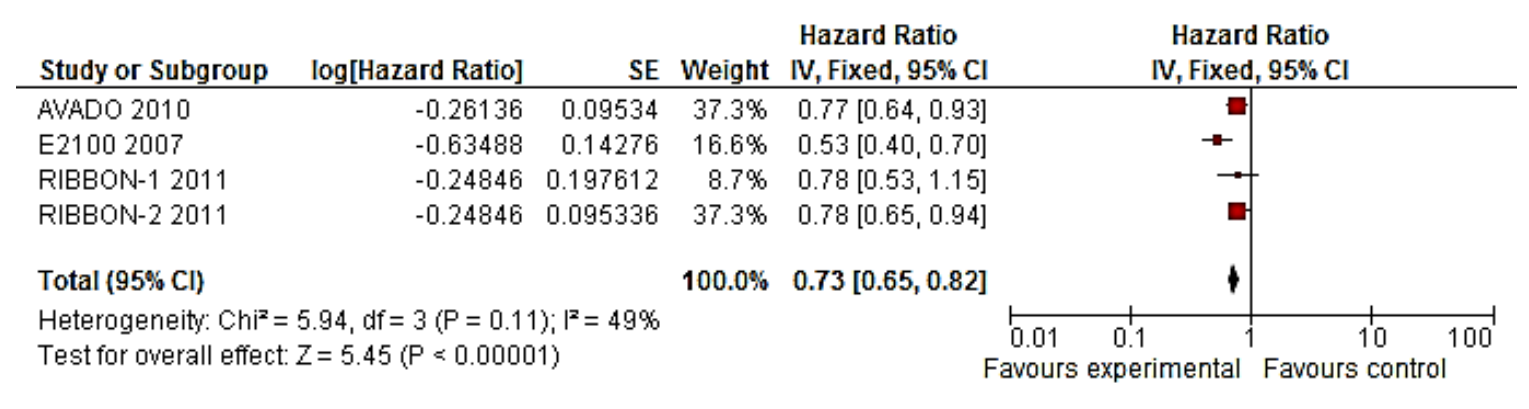

Figure 2. PFS, HER2-negative breast cancer

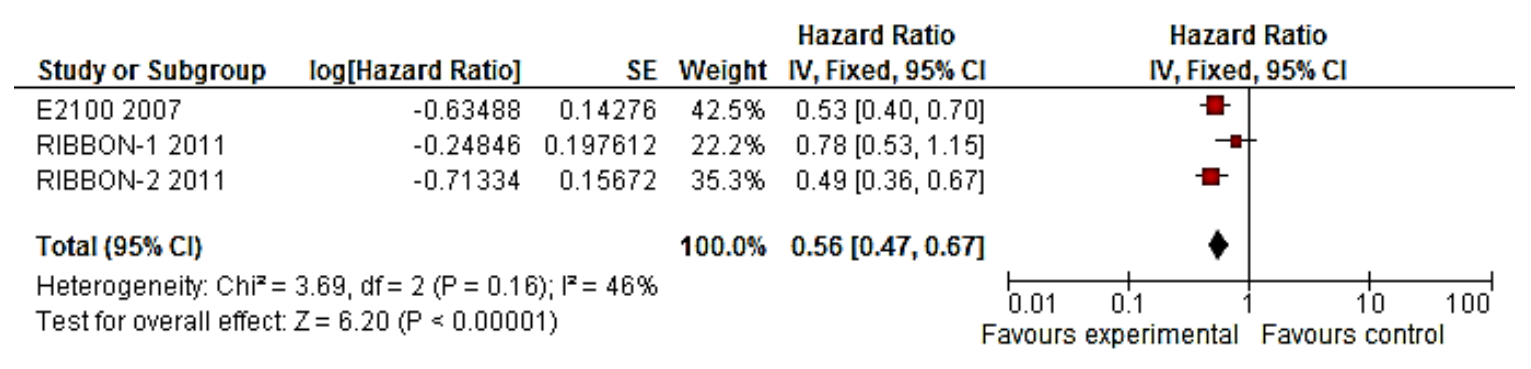

Figure 3. PFS, TNBC 


\begin{tabular}{|c|c|c|c|c|c|c|c|c|c|}
\hline \multirow[b]{2}{*}{ Study or Subgroup } & \multicolumn{2}{|c|}{ Experimental } & \multicolumn{2}{|c|}{ Control } & \multirow[b]{2}{*}{ Weight } & \multirow{2}{*}{$\begin{array}{c}\text { Risk Ratio } \\
\text { M-H, Fixed, } 95 \% \mathrm{Cl}\end{array}$} & \multirow{2}{*}{\multicolumn{2}{|c|}{$\begin{array}{c}\text { Risk Ratio } \\
\text { M-H, Fixed, } 95 \% \mathrm{Cl}\end{array}$}} & \\
\hline & Events & Total & Events & Total & & & & & \\
\hline AVADO 2010 & 159 & 247 & 112 & 241 & $51.4 \%$ & $1.39[1.18,1.63]$ & & 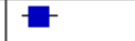 & \\
\hline RIBBON-1 2011 & 90 & 177 & 25 & 67 & $16.4 \%$ & $1.36[0.97,1.92]$ & & 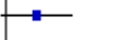 & \\
\hline RIBBON-2 2011 & 143 & 459 & 53 & 225 & $32.2 \%$ & $1.32[1.01,1.74]$ & & 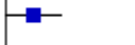 & \\
\hline Total $(95 \% \mathrm{Cl})$ & & 883 & & 533 & $100.0 \%$ & $1.36[1.19,1.56]$ & & 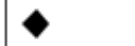 & \\
\hline Total events & 392 & & 190 & & & & & & \\
\hline $\begin{array}{l}\text { Heterogeneity: } \mathrm{Chi}^{2} \\
\text { Test for overall effec }\end{array}$ & $\begin{array}{l}0.09, \mathrm{df}= \\
Z=4.52(\mathrm{f}\end{array}$ & $\begin{array}{l}(P=0 \\
<0.00\end{array}$ & $\begin{array}{l}96) ;\left.\right|^{2}=1 \\
001)\end{array}$ & & & & $\begin{array}{|ccc|}0.1 & 0.2 & 0.5 \\
& \text { Favours control }\end{array}$ & 2 & $\begin{array}{cc}1 & 10 \\
\text { perimenta } & 10\end{array}$ \\
\hline
\end{tabular}

Figure 4. ORR, HER2-negative breast cancer

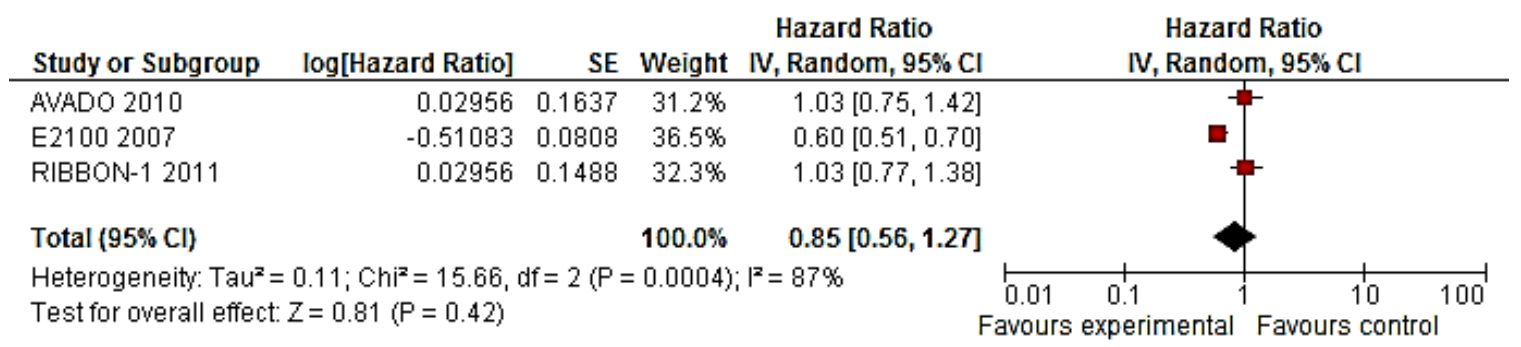

Figure 5. OS, first-line BV, HER2-negative breast cancer

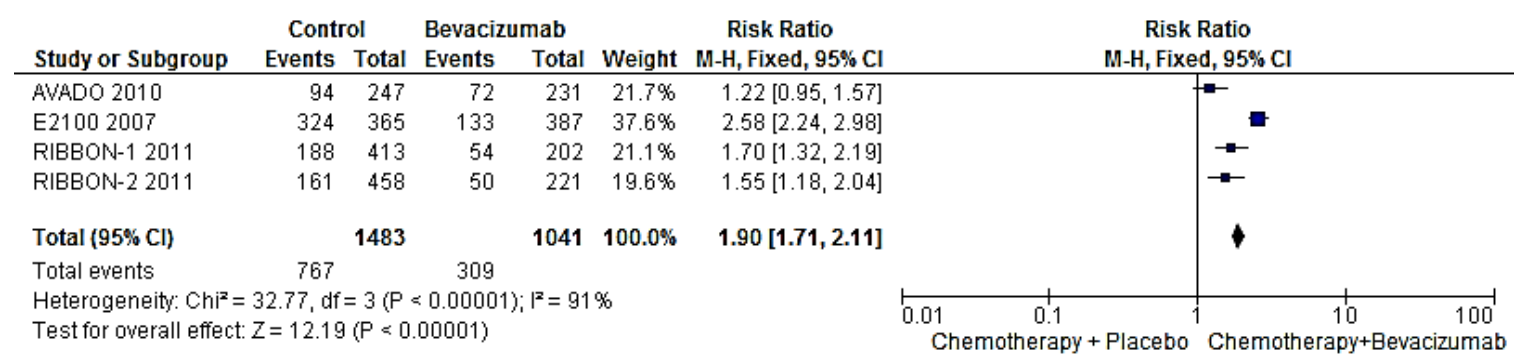

Figure 6. Grades 3-5 adverse events

\section{Discussion}

In E2100, BV was shown to be superior to placebo when added to paclitaxel as the initial treatment of metastatic HER2-negative breast cancer. It concluded that treatment with BV early in the course of $\mathrm{mBC}$, when angiogenic pathways are less redundant, improved PFS and the ORR. In this study, although the patients were being given their first chemotherapy in the metastatic setting, more than half already received chemotherapy in the adjuvant setting. Since then, there have been more questions than answers regarding the role of $\mathrm{BV}$ in advanced breast cancer.

The results of AVADO and RIBBON-1 confirmed the improvement in PFS and response rates which were earlier seen in E2100. However, the evidence was less robust in the latter two studies. RIBBON-2, designed to test the efficacy of $\mathrm{BV}$ in the second-line setting in HER2-negative breast cancer, produced similar results.

In our analysis, the PFS in all four studies were significantly increased by BV. We noted that in E2100, RIBBON-2, and RIBBON-1, there were subgroups that dealt with TNBC. We did a subgroup analysis that also revealed a statistically significant increase in PFS, which was more significant than that in the HER2-negative population alone (HER2-neg 0.73 vs TNBC 0.56). Since there is no standard treatment yet for TNBC, bevacizumab seems to be an attractive option and has indeed been explored in several studies, but these were all in the neoadjuvant (NCT00861705, NCT00786798) or adjuvant setting (NCT00528567). Results for ORR were homogenous and statistically significant in favour of BV in HER2-negative breast cancer. OS did not reach statistical significance and was heterogeneous, with only E2100 showing an increase in OS. Some argue that this was probably due to the effect of weekly paclitaxel, but there has never been another trial that confirmed this. Since we did not have access to raw data, we had to statistically derive our values.

The results of our study mirror the results of an earlier meta-analysis $^{14}$ on E2100, AVADO, and RIBBON-1. Our independent review reflects the same conclusions, even with the addition of RIBBON-2. The funnel plots below show this (Figure 7). 
Review: Bevacizumab in HER2-negative locally-recurrent and metastatic breast cancer: The BHerN Review Comparison: Bevacizumab plus chemotherapy vs Chemotherapy alone in HER2-negative locally recurrent and metastatic breast cancer Outcome: Progression-free survival

Review: Bevacizumab in HER2-negative locally-recurrent and metastatic breast cancer: The BHerN Review Comparison: Bevacizumab plus chemotherapy vs Chemotherapy alone in triple-negative locally recurrent and metastatic breast cancer Outcome: Progression-free survival

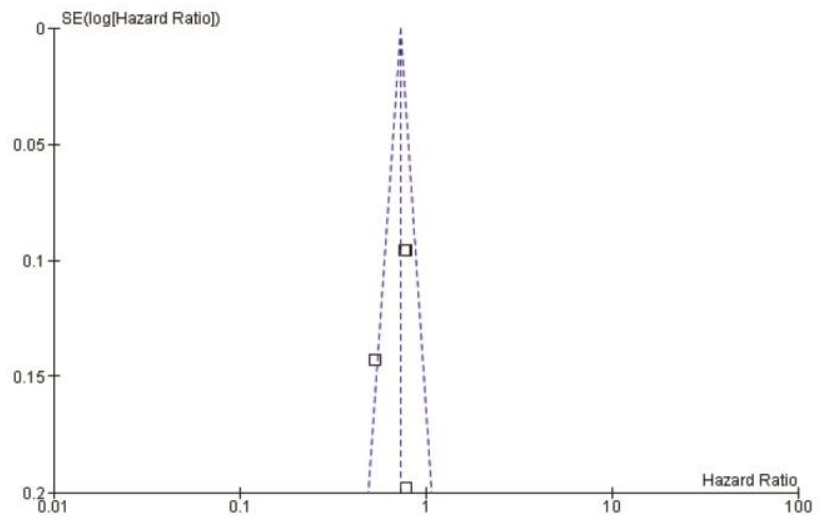

Figure 7. Funnel plots for PFS in HER2-negative and TNBC

As expected, adverse events were increased in all BV arms but fatal toxicities were not increased. There was a minimal increase in the incidence of hypertension, venous thromboembolism, and neutropenia. Bleeding events happened in $<5 \%$ of the population. In E2100, the only patient with a grade 5 event was a patient in the BV arm who suffered from a ruptured diverticulum. No grade 5 events were reported in AVADO, RIBBON-1, and RIBBON2. Majority of deaths in all four trials were related to diseaseprogression and those not related to progression balanced out in both arms.

We differ from other reviews in that our meta-analysis only included data from randomized Phase III trials. We included the objective response rates. We included only the purely HER2-negative population (excluded the HER2positive that progressed on trastuzumab or those that were using trastuzumab or those that were HER2-unknown) in the survival data. Efficacy and safety data were pooled regardless of whether it was first- or second-line chemotherapy. Nevertheless, hazard ratios of all of our findings for both PFS and OS are comparable.

The major limitation in our meta-analysis is the variability of the added chemotherapy to BV across all studies. We think that this is also the reason why the studies were heterogenous. E2100 used paclitaxel. AVADO used docetaxel. RIBBON-1 combined taxane with anthracycline or capecitabine. RIBBON-2 was more liberal with the preference of chemotherapy leaving the choice solely to the physician. This made it harder to generalize the benefit for all patients included in the analysis. However, shifting to random effects, the advantage was consistent in all studies. In the real world, this would really be the scenario since

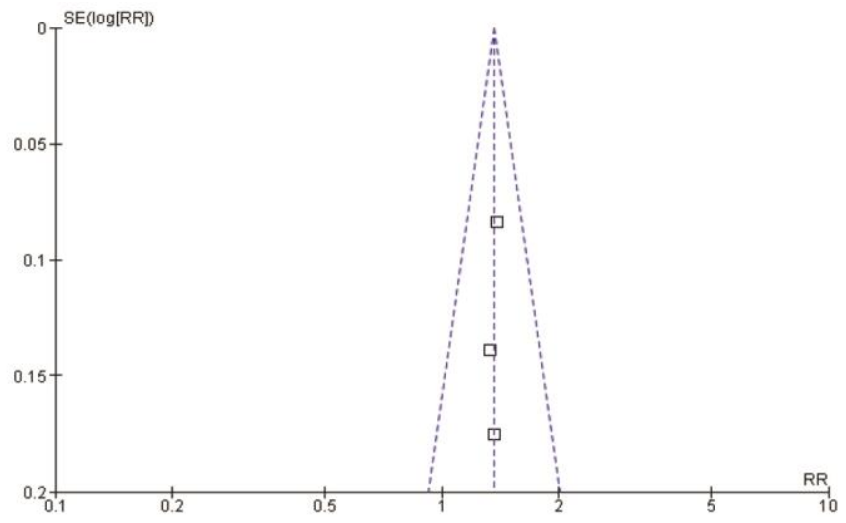

most of the patients with metastases have probably been given more than one chemotherapy regimen already that would preclude the usage of a drug used in the trials.

Her2 (-) breast cancer is also a heterogenous group of tumors that include hormonal sensitive (ER and/or PR positive tumors) as well as triple negative variants (ER, PR, Her 2 negative). Because of this, overall behavioir and patient prognosis may differ, with the hormonal sensitive variants tending to have slower growth, less propensity for visceral metastases, longer remission periods and better overall prognosis for survival compared to the triple negative variants. Hence looking at results mostly as Her2 alone may not completely evaluate the value of this combination, since the population of hormonal sensitive patients would have better prognosis and skew results to the positive side. This may be the main reason for failure to see an improvement in OS and not just the heterogeneity of chemotherapy.

Burstein $^{15}$ criticized the outcomes of E2100, AVADO, and RIBBON-1. Although statistically significant, he wrote that these trials produced outcomes that were arguably, not compelling since OS was not increased. However, more than three-fourths of oncology drugs are already approved for use based on surrogate endpoints (PFS, TTP, ORR, instead of OS). In an effort to accelerate cancer drug development and to decrease the time before a new effective agent is made available to patients, these surrogate endpoints are of vital importance. This too justifies the favourable results of our meta-analysis, even if the benefit was limited to PFS and ORR. We think that the addition of $\mathrm{BV}$ to conventional first- or second-line chemotherapy is justified in HER2-negative $\mathrm{mBC}$, and more so in TN negative 
$\mathrm{mBC}$ since there is still no standard treatment for this. As always, however, economics has also to be factored in the decision to use BV for a patient in need.

\section{References}

1. Laudico A, Medina V, Lumague M, et al. 2010 Philippine Cancer Facts and Estimates. Manila: Philippine Cancer Society Inc, 2010.

2. Dent SF. The role of VEGF in triple negative breast cancer: where do we go from here? Ann Oncol. 2009; 20(10):1615-7.

3. De Vita VT Jr, Lawrence TS, Rosenberg SA. Cancer: Principles and Practice of Oncology, $9^{\text {th }}$ ed. Philadelphia, PA, USA: JB Lippincott, 2011.

4. Slamon DJ, Clark GM, Wong SG, Levin WJ, Ullrich A, McGuire WL. Human breast cancer: correlation of relapse and survival with amplification of the HER-2/neu oncogene. Science. 1987; 235(4785):17782.

5. Slamon DJ, Godolphin W, Jones LA, et al. Studies of the HER-2/neu proto-oncogene in human breast and ovarian cancer. Science. 1989; 244(4905):707-12.

6. Slamon DJ, Leyland-Jones B, Shak S, et al. Use of chemotherapy plus a monoclonal antibody against HER2 for metastatic breast cancer that over-expresses HER2. N Engl J Med. 2001; 344(11):783-92.

7. Ferrara N, Gerber HP, LeCouter J. The Biology of VEGF and its receptors. Nat Med. 2003; 9(6):669-76.

8. Hanahan D, Folkman J. Patterns and emerging mechanisms of the angiogenic switch during tumorigenesis. Cell. 1996; 86(3):353-64.

9. Jain RK. Normalizing tumor vasculature with anti-angiogenic therapy; a new paradigm for combination therapy. Nat Med. 2001; 7(9):987-9.

10. Relf M, Lejeunne S, Scott PA, et al. Expression of the angiogenic factors vascular endothelial cell growth factor, acidic and basic fibroblast growth factor, tumor growth factor beta-1, platelet-derived endothelial cell growth factor, placenta growth factor and pleiotrophin in human primary breast cancer and its relation to angiogenesis. Cancer Res. 1997; 57(5):963-9.

11. Alvarez RH, Guarneri V, Icli F, et al. Bevacizumab treatment for advanced breast cancer. Oncologist. 2011; 16(12):1684-97.

12. Miles D, Harbeck N, Escudier B, et al. Disease course patterns after discontinuation of bevacizumab: pooled analysis of randomized phase III trials. J Clin Oncol. 2011; 29(1):83-8.

13. Dangi CBS, Firodiya A. Triple Negative Breast Cancer and its therapeutic options. IJPBS. 2012; 3(2):130-65.

14. Rossari JR, Metzger-Filho O, Paesmans M, et al. Bevacizumab and Breast Cancer: A Meta-Analysis of First-Line Phase III Studies and a Critical Reappraisal of Available Evidence. J Oncol. 2012; 2012: 417673.

15. Burstein HJ. Bevacizumab for advanced breast cancer: all tied up with a RIBBON. J Clin Oncol. 2011; 29(10):1232-5. 
Appendix 1. Characteristics of Excluded Trials

\begin{tabular}{|c|c|c|c|c|}
\hline Study & Method & Participants & Intervention & Outcome \\
\hline $\begin{array}{l}\text { A Phase II Trial of Bevacizumab and ABI-007 } \\
\text { (Abraxane) as Second-line Therapy in Her-2 } \\
\text { Negative, Hormone Receptor Negative } \\
\text { Metastatic Breast Cancer }\end{array}$ & Cohort & $\begin{array}{l}\text { Disease progression after at least } \\
\text { one prior chemotherapy regimen } \\
\text { for metastatic disease or within } \\
12 \text { months of adjuvant } \\
\text { chemotherapy initiation } \\
\end{array}$ & Bevacizumab, Abraxane & $\begin{array}{l}\text { Primary: PFS } \\
\text { Secondary: RR }\end{array}$ \\
\hline $\begin{array}{l}\text { A Phase II Study of Abraxane }{ }^{\circledR}, \text { Carboplatin and } \\
\text { Bevacizumab in Triple Negative Metastatic } \\
\text { Breast Cancer }\end{array}$ & Cohort & $\begin{array}{l}\text { Patients may have received } 0 \text { - } 1 \\
\text { prior therapies (except taxanes } \\
\text { in the metastatic setting) }\end{array}$ & $\begin{array}{l}\text { Abraxane } \\
\text { Bevacizumab } \\
\text { Carboplatin }\end{array}$ & $\begin{array}{l}\text { Primary: Safety } \\
\text { Secondary: PFS }\end{array}$ \\
\hline $\begin{array}{l}\text { Adjuvant Doxorubicin, Cyclophosphamide } \\
\text { Followed by Avastin Given With Paclitaxel and } \\
\text { Gemcitabine for Stage II and III Breast Cancer } \\
\text { That Does Not Over-express HER-2/Neu }\end{array}$ & Cohort & $\begin{array}{l}\text { HER2-negative Breast Cancer } \\
\text { Stage II toBreast Cancer } \\
\text { Stage IIIC }\end{array}$ & $\begin{array}{l}\text { doxorubicin } \\
\text { cyclophosphamide } \\
\text { bevacizumab } \\
\text { paclitaxel } \\
\text { gemcitabine } \\
\end{array}$ & $\begin{array}{l}\text { Primary: Feasibility, DFS, } \\
\text { OS }\end{array}$ \\
\hline $\begin{array}{l}\text { Docetaxel-epirubicin Plus Bevacizumab as First } \\
\text { Line Therapy for Patients With Metastatic and } \\
\text { HER2 Negative Breast Cancer. A Multicenter } \\
\text { Phase I-II Study }\end{array}$ & Cohort & HER2-negative Breast Cancer & $\begin{array}{l}\text { Docetaxel } \\
\text { Epirubicin } \\
\text { Bevacizumab }\end{array}$ & $\begin{array}{l}\text { Primary: ORR } \\
\text { Secondary: Toxicity, TTP, } \\
\text { OS }\end{array}$ \\
\hline AVF 2119 & RCT & $\begin{array}{l}\text { Previously Treated Metastatic } \\
\text { Breast Cancer }\end{array}$ & Bevacizumab & $\begin{array}{l}\text { Primary: } \\
\text { Efficacy, Safety }\end{array}$ \\
\hline Sabre-B & RCT & Metastatic Breast Cancer & $\begin{array}{l}\text { Bevacizumab } \\
\text { sunitinib } \\
\text { paclitaxel }\end{array}$ & $\begin{array}{l}\text { Primary: Best response } \\
\text { Secondary: SAEs }\end{array}$ \\
\hline $\begin{array}{l}\text { Study of Avastin (Bevacizumab) and Sequential } \\
\text { Chemotherapy in Patients With Primary HER2 } \\
\text { Negative Operable Breast Cancer }\end{array}$ & Non-RCT & $\begin{array}{l}\text { Operable Her2 negative breast } \\
\text { CA }\end{array}$ & $\begin{array}{l}\text { bevacizumab Docetaxel } \\
\text { Standard chemotherapy }\end{array}$ & $\begin{array}{l}\text { Primary: Pathologic } \\
\text { complete response } \\
\text { Secondary: CRR }\end{array}$ \\
\hline $\begin{array}{l}\text { A Multi Phase II Clinical Trials Evaluating the } \\
\text { Association of Bevacizumab With Weekly } \\
\text { Paclitaxel and Capecitabine in First Line } \\
\text { Treatment for Patients With Triple Negative } \\
\text { Metastatic or Locally Advanced Cancer }\end{array}$ & Non-RCT & $\begin{array}{l}\text { Triple Negative Metastatic } \\
\text { Breast Cancer }\end{array}$ & $\begin{array}{l}\text { Paclitaxel } \\
\text { Bevacizumab } \\
\text { Capecitabine }\end{array}$ & Primary: ORR \\
\hline
\end{tabular}

Appendix 2. Characteristic of Ongoing Studies

\begin{tabular}{|c|c|c|c|c|}
\hline Study & Method & Participants & Intervention & Outcome \\
\hline $\begin{array}{l}\text { A Phase II Trial of Doxil, Carboplatin and } \\
\text { Bevacizumab in Triple Negative Previously } \\
\text { Untreated Metastatic Breast Cancer }\end{array}$ & Cohort & $\begin{array}{l}\text { Women with previously } \\
\text { untreated metastatic breast } \\
\text { cancer, ER/PR/HER2/neu } \\
\text { negative }\end{array}$ & $\begin{array}{l}\text { Doxil } \\
\text { Carboplatin } \\
\text { Bevacizumab }\end{array}$ & $\begin{array}{l}\text { Primary: PFS } \\
\text { Secondary: RR }\end{array}$ \\
\hline $\begin{array}{l}\text { A Randomized, Double-Blind, Placebo- } \\
\text { Controlled Phase II Trial of Weekly } \\
\text { Paclitaxel/Bevacizumab +/- Everolimus as First- } \\
\text { Line Chemotherapy for Patients With HER2- } \\
\text { Negative Metastatic Breast Cancer (MBC) }\end{array}$ & RCT & $\begin{array}{l}\text { HER2-negative breast cancer } \\
\text { No prior chemotherapy for MBC }\end{array}$ & $\begin{array}{l}\text { EverolimusBevacizumab } \\
\text { Paclitaxel } \\
\text { Placebo }\end{array}$ & $\begin{array}{l}\text { Primary: PFS } \\
\text { Secondary: RR,CR,PR }\end{array}$ \\
\hline $\begin{array}{l}\text { A Phase III Clinical Trial Comparing the } \\
\text { Combination of TC Plus Bevacizumab to TC } \\
\text { Alone and to TAC for Women With Node- } \\
\text { Positive or High-Risk Node-Negative, HER2- } \\
\text { Negative Breast Cancer }\end{array}$ & RCT & $\begin{array}{l}\text { breast cancer must be HER2- } \\
\text { negative based on current } \\
\text { ASCO/CAP Guideline } \\
\text { Recommendations }\end{array}$ & $\begin{array}{l}\text { bevacizumab } \\
\text { Drug: docetaxel } \\
\text { Drug: doxorubicin } \\
\text { Drug: cyclophosphamide } \\
\text { Drug: pegfilgrastim }\end{array}$ & $\begin{array}{l}\text { Primary: IDFS } \\
\text { Secondary: DFS-DCIS }\end{array}$ \\
\hline $\begin{array}{l}\text { Phase II Study Evaluating the Efficacy and } \\
\text { Tolerance of Bevacizumab (Avastin) in HER2- } \\
\text { Inflammatory Breast Cancer }\end{array}$ & Cohort & $\begin{array}{l}\text { HER2-negative, inflammatory } \\
\text { breast cancer }\end{array}$ & $\begin{array}{l}\text { bevacizumab } \\
\text { cyclophosphamide } \\
\text { docetaxel } \\
\text { epirubicin hydrochloride } \\
\text { fluorouracil } \\
\end{array}$ & $\begin{array}{l}\text { Primary: } \\
\text { HRR } \\
\text { PFS, OS }\end{array}$ \\
\hline $\begin{array}{l}\text { Phase } 2 \text { Study of AMG } 386 \text { Plus Paclitaxel With } \\
\text { or Without Bevacizumab as First Line Therapy in } \\
\text { Her2-Negative Breast Cancer Patients }\end{array}$ & RCT & $\begin{array}{l}\text { Locally Recurrent and Metastatic } \\
\text { Breast Cancer, Her2 negative }\end{array}$ & $\begin{array}{l}\text { AMG } 386 \text { Bevacizumab } \\
\text { Paclitaxel }\end{array}$ & $\begin{array}{l}\text { Primary: PFS } \\
\text { Secondary:DOR, TTP, OR }\end{array}$ \\
\hline BEATRICE Study & RCT & TNBC & $\begin{array}{l}\text { bevacizumab } \\
\text { Standard adjuvant } \\
\text { chemotherapy }\end{array}$ & $\begin{array}{l}\text { Primary: } \\
\text { Invasive DFS } \\
\text { Secondary Outcome: OS, } \\
\text { DFS }\end{array}$ \\
\hline
\end{tabular}

